\title{
Prologue to the Third Edition
}

W work on the Shi'i community began in tumultutoppled, Iraq was about to invade Iran (launching a savage eight-year war), and Lebanon, in the midst of civil war and ever permeable to external influence, was divided into militia fiefdoms supported by regional and global rivals. Next door in Syria, the legitimacy of the al-Asad regime was being challenged by Islamist opponents who would soon be pitilessly obliterated along with much of the city of Hama in 1981. The most significant nonstate actor in the Arab world was the Palestine Liberation Organization, then dismissed by Israel as "terrorist." Shi i Hezbollah did not yet exist (its establishment is discussed in chapter 2).

In the four decades that have passed since my interest in Lebanon began, the country has enjoyed peaceful, prosperous interludes, and some Lebanese have managed to insulate themselves from disorder and violence or lose themselves in the rampant consumerism of Beirut. Others have made new lives as expatriates. It is sobering to consider how often invasion, warfare, dislocation, or the threats of impending disaster have impinged on daily life in Lebanon. Too many of the people whom I first encountered in the early 1980s or later have died violently: three were assassinated; others fell in battle or were otherwise victims of violence. As this updated version of Hezbollah goes to press, a seven-year civil war in Syria is entering a new phase-in which the government is attempting to restore 
its authority over a shattered country, in which more than half of the population has been internally displaced or fled as refugees. Hezbollah, the focus of this book, played a major role in defeating rebel forces and enabling the government's survival. Meantime, ominous storm clouds hang over Lebanon, where bad weather hardly stops at the border.

Hezbollah emerged in the early 1980s following the Israeli invasion of Lebanon in 1982. A variety of militant Shi'i factions, inspired by the 1978-79 Islamic Revolution in Iran and actively supported by Iran, competed for support. It would take a couple of years for Hezbollah to coalesce as an organization and to subsume many of its competitors. Hezbollah declared its commitment to replicating Iran's revolution in Lebanon, but this was hardly a widely shared view. Nor was Hezbollah the dominant Shi'i group of the 1980s. That distinction belonged to the reformist and popular Amal movement, which was seeking a seat at the political table in Beirut, while Hezbollah, at that time, rejected participating in the political system at all.

Even before Hezbollah was formally constituted, several of its most infamous members, working in league with Iran, carried out extraordinary attacks in Lebanon, including October 1983 truck bombings against U.S. marine and French paratrooper bases in Beirut, resulting in the death of over 300 people, including 241 U.S. service members and 58 French soldiers (see chapter 4). Hezbollah also gained worldwide notoriety for its leading role in holding foreigners hostage in the 1980s and early 1990s. Some hostages were held for years under savage conditions, and others-including CIA station chief William Buckley and marine Lieutenant Colonel Richard Higgins-died in captivity after merciless beatings and torture. These, and a 
variety of other violent acts, earned Hezbollah the enduring enmity of many Western officials.

In another realm, however, Hezbollah developed a reputation for professionalism and competence for its role in attacking the occupying Israeli military and its Lebanese proxy forces. Rather than withdrawing from Lebanon following its 1982 invasion, Israel retained control of about ten percent of Lebanese territory abutting its border. Hezbollah was by no means the only group resisting the occupation, but as time passed it established itself as the most lethal and effective group. Arguably, Israel's eventual exit from Lebanon in 2000 would not have occurred without the pressure posed by Hezbollah.

By the late 1980s, Hezbollah was directly confronting the more moderate Amal movement. While Amal has maintained a base of support in the Shi'i community, Hezbollah succeeded in supplanting it in the environs of Beirut, particularly in the populous Shi'i suburbs south of the city. Equally significant, Hezbollah was institutionalizing itself as a political party and earning a reputation for competence and honesty. In contrast, Amal often functioned more as a top-down patronage network. As a result, many former supporters of Amal shifted their support to Hezbollah. Less than a decade following its creation, Hezbollah became the dominant group in Lebanon's Shi'i community.

Hezbollah was evolving from an Iranian-sponsored extremist group that rejected participation in Lebanese politics to a party with considerable autonomy and a talent for playing politics and winning elections. It became a Shi'i political party with a large base of popular support, and, contradicting its early stance, even became part of 
the Lebanese government. Simultaneously, it is Lebanon's most powerful military force. And it has not been beneath flaunting that power to get its way. (Chapter 5 describes and analyzes the organization's evolution and its complex profile on the Lebanese political landscape.)

Especially since the intense 2006 war with Israel (the focus of chapter 6), an overwhelming majority of the Shia has embraced Hezbollah as the defender of their community. Hezbollah's security narrative, if not its worldview, suddenly became compelling, not simply for ardent Hezbollahis but even for many apolitical and avowedly secular Shi'i Muslims. The plausibility of Hezbollah's security narrative-that the Shi'a must protect themselves because the Lebanese Army is incapable of doing so and no one else will-is a crucial explanation for the uncommon unity one finds among many Shi'a Muslims today. This suggests that outsiders such as the United States or France seeking to reduce Hezbollah's influence in Lebanon must redress the security narrative rather than take steps that validate it. However legitimate Israel's concerns may be about Hezbollah's military capacity and its armory, not to mention its deep-seated hatred toward Israel, it is foolhardy to consider Hezbollah's strength without acknowledging how widely and how often the Lebanese, and especially Shi'i Lebanese, have suffered from Israel's disproportionate violence.

Hezbollah proved to have a tin ear when it came to politics in Syria. Its initial response to the so-called Arab Spring was calm and self-assured. When Egyptian president Husni Mubarak was toppled in February 2011, many Hezbollah supporters were gleeful that an arch foe, who had lent strong support to the Shi i group's Lebanese rivals, had fallen from power. As for Iran, leading regime figures 
incredulously claimed that the Islamic Revolution had inspired the Egyptian protestors. In fact, the Iranian regime was widely viewed in Arab countries as both repressive and alien. Hezbollah was little concerned that the group's close ally in Damascus would be threatened at all. It turned out that Hezbollah shared in the Syrian government's selfdelusions. Al-Asad's armed forces not only failed to suppress its internal opposition but also precipitated a civil war that imposed destitution, death, and destruction on its own citizens. By 2017, over 400,000 people had been killed in the war, many of them civilians and most at the hands of the government.

Inspired by the initial successes of the uprisings that erupted in Tunisia, Egypt, Bahrain, and Yemen, Syrians mounted peaceful demonstrations beginning in March 2011. The Damascus regime responded ruthlessly. Of course, the iron fist response failed to squash the protests, and as the opposition turned to bullets and bombs, floods of refugees began to cross borders into neighboring countries, including in Lebanon, where well over a million refugees sought safety by 2016. Considering that citizens represent just over four million people, the refugee influx has been calamitous for the small country's stability and treasury. The World Bank estimated in 2017 that the Syrian civil war and refugee challenge costs Lebanon about $\$ 7.5$ billion annually.

Many Lebanese would naturally prefer to keep these regional catastrophes at arm's length, praying that what happens in Syria, in particular, stays in Syria. Notwithstanding the efforts of leading Lebanese political figures to avoid entanglement in Syria and maintain a neutral stance of disassociation, the creeping encroachment of the Syrian 
civil war proved to be unstoppable. The two countries are intertwined economically, culturally, and politically. Well before Hezbollah's high-profile intervention in Syria bolstered the regime in the spring of 2013, hopes of neutrality faded amid cross-border shoot-outs, ambushes, kidnappings, floods of Syrian refugees entering Lebanon, and the counterflow of Lebanese to join the fight in Syria.

My impression, which is shared by a number of other close observers, is that the Lebanese are split about halfand-half concerning which side they support in Syria. Three decades of Syrian domination of Lebanon ended only in 2005, and many who suffered would celebrate the fall of the al-Asad regime. It must be said, however, that large numbers of Lebanese, including many Christians as well as Muslims, continue to see the Syrian regime in a favorable light, considering the alternative. They note that it has protected minorities, and they fear the prospect of a new regime in which extreme jihadist groups would pose a lethal threat to those who do not embrace a Salafist interpretation of Islam.

The survival of the Syrian regime was a strategic imperative for Hezbollah, which feared the rise of a hostile government dominated by jihadists who would jeopardize the group's weapons flow and probably align with Saudi Arabia. Iran, of course, came to similar conclusions. It is debatable whether Hezbollah's intervention was simply at the behest of Iran, because the logic of Hezbollah's calculations was independently compelling. Hezbollah's decision to side openly with the Damascus regime in the fighting provoked an angry response from Salafist Sunni preachers in Lebanon who declared a jihad in Syria and rallied supporters to strike back at Hezbollah. Syrian opposition forces vowed to bring their war to Lebanon, and they did 
so with massive car bombs and artillery salvos on Hezbollah's urban stronghold in southern Beirut. As the war progressed, areas populated by Shi'a were festooned with posters of martyrs who had fallen in Syria.

Hezbollah's intervention-combined with the role of Iran and a variety of militias manned by Iraqi, Afghan, Pakistani and other Shi'a, and the addition of Russian air power, artillery and battlefield coordination-insured the survival of the Syrian regime. But the civil war will have no neat conclusion. Rebel groups survive in some of the provinces, while U.S.-supported Kurdish and Arab forces have enjoyed success in the campaign against ISIS held cities and towns. Turkey, intensely concerned with Syrian Kurds and their ambitions for autonomy, which Ankara opposes, and with continuing links to residual rebel groups, will have in hand in determining the outcome. In this context, it will be hard for Hezbollah to disentangle itself from Syria, even though the strategic outcome of the civil war is obvious.

Indeed, as noted in the conclusion, with the end of heavy combat in Syria, Lebanon is likely to enter a period of dangerous instability. Saudi-Iranian jousting was already a main event in Lebanon, and Saudi Arabia has signaled its intention of checking Iranian influence in Lebanon and undermining Hezbollah. The Saudis see the group playing a major role bolstering Iran's position in Iraq. Hezbollah members played a major role in training Iraqi militiamen, including in the use of lethal explosives against U.S. forces up until 2011. More recently, the Saudis accuse Iran and Hezbollah of helping Yemeni Houthis, who have defied Saudi-led efforts to defeat them, despite a brutal three-yearlong military campaign. By late 2017, the Saudis pressured the Lebanese Sunni prime minister to resign from office to delegitimize the Lebanese government, called on its 
citizens to leave Lebanon (a step followed by Bahrain and Kuwait), and threatened punitive economic steps. These steps are probably a sampling of others to come. It is unclear where the U.S. stands on these measures, although President Donald Trump has been broadly supportive of Saudi Arabia.

Equally significant and worrisome for the group's partisans is Hezbollah's loss of popular esteem in the Arab world (addressed in chapter 7). In contrast to high-flying days following the 2006 war, when Hezbollah's virtues and battlefield exploits were widely celebrated, the group is now commonly derided around the Arab world and in the ubiquitous Saudi-funded media for its connections to the reviled theocracy in Iran, its implication in the assassination of former prime minister Rafiq al-Hariri in 2005, and for its alleged involvement in terrorist attacks. The decision of the European Union in 2013 to designate Hezbollah's military wing as a terrorist group added to the ostracism, which increased further when Hezbollah was denounced as a terrorist group by the Gulf Cooperation Council and most members of the Arab League.

Hezbollah is a formidable entity with deep support in Lebanon among a vast majority of the Shii i community, as well as many Lebanese Christians. It has proven to be a resolute and competent military force and a highly institutionalized party. It has spread an ethos that is deeply resonant among many of its followers and it boasts robust support from Iran, for which it is a showcase success story. Even so, its foes are many, including those provoked by Hezbollah's support and training for opponents in places like Iraq. Its strong hand in Lebanon provokes its opponents to try to chop it down to size. In the process, efforts 
Prologue to the Third Edition

to limit Hezbollah's influence and confront Iran's geopolitical gains are likely to threaten the stability of precarious countries such as Lebanon. Without doubt, Hezbollah has affected the recent history of the Arab world, and the story is hardly over. 


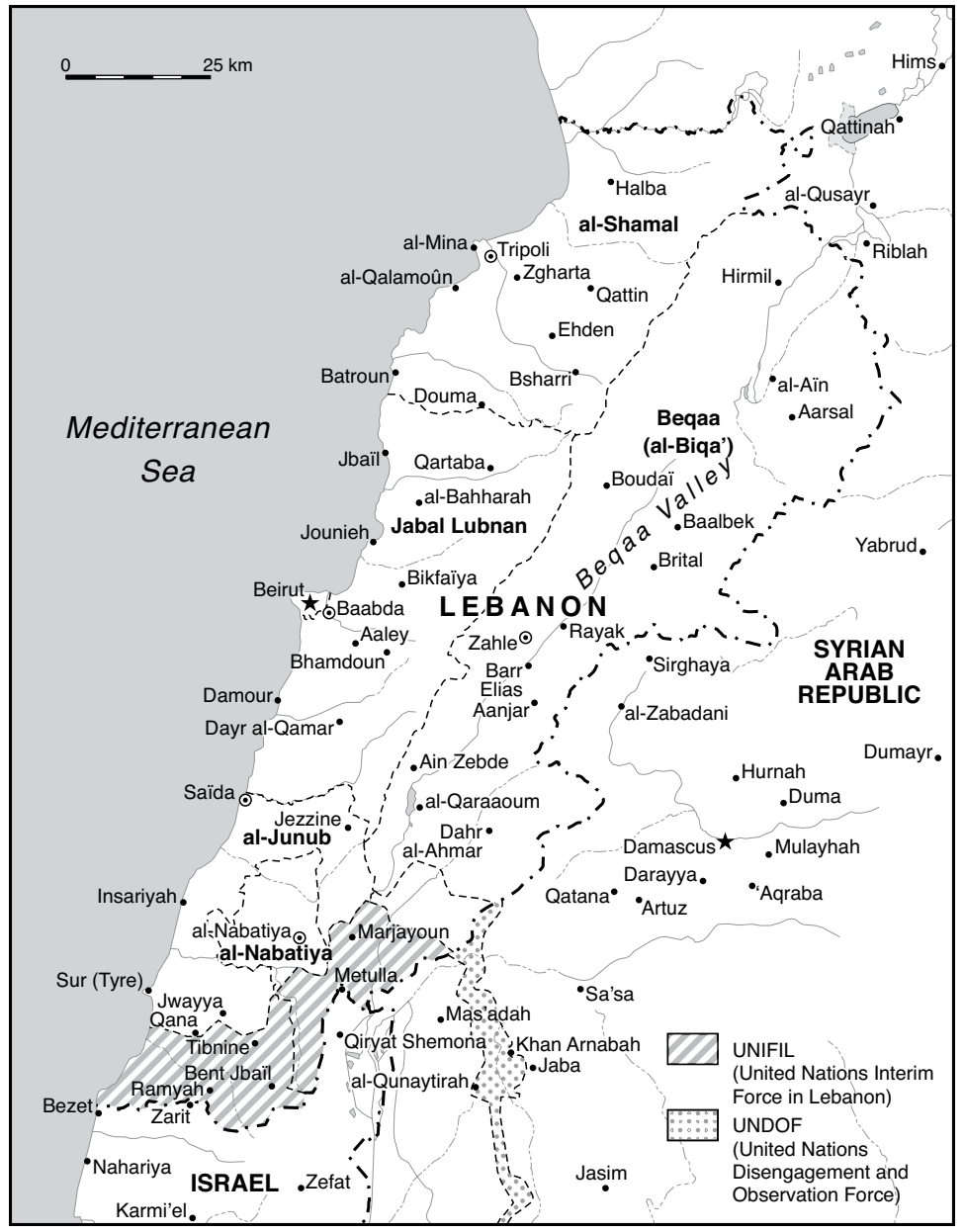

MAP 1 Major cities, and some important towns and villages, as well as Lebanon's six provinces and the areas of deployment of United Nations peacekeepers. 